\section{Metabolism of Coumarin by a Micro-organism}

RECENT reports described the isolation of a soil organism (Arthrobacter sp.) as the source of an enzyme which reduced $o$-coumaric acid to melilotic acid ${ }^{1-3}$. The present communication describes further studies on this enzyme which suggest that it is a flavoprotein and that the flavin moioty is FAD.

The organism was cultured with coumarin as its sole carbon source, and collected as previously described ${ }^{1,2}$. To demonstrate the role of a flavin in the reaction, the enzyme purification described earlier ${ }^{2}$ was modified as follows: The enzyme, obtained after ammonium sulphate precipitation, was treated once again with calcium phosphate gel and the mixture clarified by centrifugation at $75,000 \mathrm{~g}$ for $30 \mathrm{~min}$. The supernatant solution was then brought to 50 per cent saturation with solid ammonium sulphate and, after cooling for $30 \mathrm{~min}$, the suspension was centrifuged at $75,000 \mathrm{~g}$ for $30 \mathrm{~min}$. The precipitate was redissolved in a volume of water equal to the original volume of crude extract. This enzyme was dialysed against 41 . of water changed three times during a $24-\mathrm{h}$ period. This preparation was used in all the experiments reported here.

Attempts to separate the flavin from the protein using ammonium sulphate precipitation followed by treatment with acid, as described by Strittmatter ${ }^{4}$, were unsuccessful in that the enzyme was irreversibly inactivated. It was found that the above modification of the original purification procedure ${ }^{2}$ separated the flavin from the apoenzyme with only minimal loss of enzyme activity.

Table 1 shows the effects of the addition of various flavins on NADH : $o$-coumarate oxidoreductase. It can be seen that FAD at $6 \cdot 6 \times 10^{-5} \mathrm{M}$ doubled the activity of the enzyme. The other flavins were virtually without effect. When FAD was added after the addition of inhibiting concentrations of partial structural analogues of FAD or various anions (Table 2 ), activity was in most cases restored to greater than control levels. Other flavins such as FMN and riboflavin either had no effect, or inhibited enzyme activity. It appears, therefore, that FAD is a specific co-factor for $\mathrm{NADH}: 0$-coumarate oxidoreductase.

The reduced form of $\mathrm{FAD}\left(\mathrm{FADH}_{2}\right)$ bound to the enzyme surface may function as the direct electron donor in the reduction of $o$-coumaric acid to molilotic acid.

It has been shown that the enzyme, $\mathbf{D}$-amino-acid oxidase, a flavoprotein isolated from pig kidneys $s^{5,6}$, was inhibited by various anions, as well as by partial structural analogues of FAD. In both cases, FAD added to the reaction mixture restored the lost activity ${ }^{5,6}$. The interprotation of these data was that FMN and the structural analogues exerted their inhibition by competing with FAD for binding sites on the protein. The inhibition by anions was alleged to represent competition with dissociated phosphoryl groups in FAD. The results of studies with NADH : o-coumarate oxidoreductase suggest that it is similar to D-amino-acid oxidase with respect to the manner in which the FAD is bound to the apoenzyme.

$o$-Coumaric acid and dihydrocoumarin were purchased from $K$ and $K$ Laboratories, Inc. Melilotic acid was prepared as described previously ${ }^{2}$. NADH was purchased from Pabst Laboratories, Inc. FAD, FMN, riboflavin, adenine, adenosine, adenylic acid, ADP and ATP were

Table 1. Effect of Variods Flavin Compounds on NADH : o-Coumarate OXIDOREDUCTASE ACTIVITY

$$
\begin{aligned}
& \text { Co-factor added } \\
& \text { Control } \\
& \text { FAD } \\
& \text { FAD } \\
& \text { FMN } \\
& \text { Riboflavin }
\end{aligned}
$$$$
\text { Final concentration }
$$
m $\mu$ Moles NADH

$$
\begin{aligned}
& 6.6 \times 10^{-5} \mathrm{M} \\
& 1.3 \times 10^{-4} \mathrm{M}
\end{aligned}
$$$$
\begin{aligned}
& 6.6 \times 10^{-5} \mathrm{M} \\
& 6.6 \times 10^{-5} \mathrm{M}
\end{aligned}
$$

100

200

116

The basic reaction mixture contained in a total volume of $3 \mathrm{ml}$. consisted of the following: $440 \mathrm{~m} \mu$ moles of $\theta$-coumaric acid; $300 \mathrm{~m} \mu$ moles of NADH; $0.1 \mathrm{ml}$. of enzyme, and $4.8 \mathrm{~m} \mu$ moles phosphate buffer, $p \mathrm{H} 7 \cdot 3$. When at flavin was included in the reaction mixture, there was a proportionate reduction in the volume of buffer added. Enzymatic activity was assayed spectrophotometrically by recording the decrease in absorbancy of NADH at $340 \mathrm{~m} \mu$ over a 60 -see interval.

\begin{tabular}{|c|c|c|c|c|}
\hline $\begin{array}{l}\text { Salt or partial } \\
\text { analogue added }\end{array}$ & $\begin{array}{l}\text { Hinal } \\
\text { concen- } \\
\text { tration }\end{array}$ & $\begin{array}{l}\text { Flavin } \\
\text { added }\end{array}$ & $\begin{array}{c}\text { Final } \\
\text { concentration }\end{array}$ & $\begin{array}{l}\text { mumoles } \\
\text { NADH oxid } \\
\text { ized/min }\end{array}$ \\
\hline Control & & & 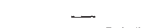 & 100 \\
\hline Adenosine & $5 \times 10^{-4} \mathrm{M}$ & FAD & $6 \cdot 6 \times 10^{-5} \mathrm{M}$ & 188 \\
\hline AMP & $5 \times 10^{-4} \mathrm{M}$ & $\mathrm{FAD}$ & $6.6 \times 10^{-5} \mathrm{M}$ & 175 \\
\hline $\mathrm{ADP}$ & $5 \times 10^{-4} \mathrm{M}$ & FAD & $6.6 \times 10^{-6} \mathrm{M}$ & 188 \\
\hline ATP & $5 \times 10^{-4} \mathrm{M}$ & $\mathrm{FAD}$ & $6.6 \times 10^{-5} \mathrm{M}$ & 181 \\
\hline ATP & $5 \times 10^{-1} \mathrm{M}$ & FMN & $6.6 \times 10^{-5} \mathrm{M}$ & 99 \\
\hline ATP & $5 \times 10^{-1} \mathrm{M}$ & Riboflavin & $6.6 \times 10^{-5} \mathrm{M}$ & 86 \\
\hline Sodium acetate & $0.1 \mathrm{M}^{\mathrm{N}}$ & FAD & $1.3 \times 10^{-4} \mathrm{M}$ & 113 \\
\hline Potassium iodide & $0 \cdot 1 \mathrm{M}$ & FAD & $1.3 \times 10^{-4} \mathrm{M}$ & 128 \\
\hline Sodium chloride & $0.1 \mathrm{M}$ & FAD & $1.3 \times 10^{-4} \mathrm{M}$ & 100 \\
\hline Sodium chloride & $0.1 \mathrm{M}$ & FMN & $6.6 \times 10^{-5} \mathrm{M}$ & 29 \\
\hline Sodium chloride & $0.1 \mathrm{M}$ & Riboflavin & $6 \cdot 6 \times 10^{-5} \mathrm{M}$ & 19 \\
\hline Sodium sulphate & $0.1 \mathrm{M}$ & FAD & $1.3 \times 10^{-4} \mathrm{M}$ & 100 \\
\hline
\end{tabular}

Table 2. (A) EFFect of Anions and Partial Strectural Analogues OF FAD ON NADH : o-COUMARATE OXIDOREDUCTASE ACTIVITY

$\begin{array}{lcc}\begin{array}{c}\text { Salt or partial } \\ \text { analogue added }\end{array} & \text { Concentration } & \begin{array}{c}\text { m } \mu \text { moles NADH } \\ \text { oxidized/min }\end{array} \\ \text { Control } & 5 \times 10^{-4} \mathrm{M} & 100 \\ \text { Adenine } & 5 \times 10^{-4} \mathrm{M} & 100 \\ \text { Adeniosine } & 5 \times 10^{-4} \mathrm{M} & 99 \\ \text { AMP } & 5 \times 10^{-4} \mathrm{M} & 69 \\ \text { ADP } & 5 \times 10^{-4} \mathrm{M} & 75 \\ \text { ATP } & 0 \cdot 1 \mathrm{M} & 75 \\ \text { Sodium acetate } & 0 \cdot 1 \mathrm{M} & 63 \\ \text { Potassium iodide } & 0 \cdot 1 \mathrm{M} & 67 \\ \text { Sodium chloride } & 0.1 \mathrm{M} & 44 \\ \text { Sodium sulphate } & & \end{array}$

(b) EFfect of Flavins on NADH : o-Codmarate OxIdoneductase AOTIVITY IN PRESENCE OF VARIOUS ANIONS OR PARTIAI. STRUCTURA

The reaction mixtures were essentially the same as those of Table 1 . To maintain the total volume of $3 \mathrm{ml}$. when a flavin and/or inhibitor were included in the reaction mixture, proportionately less buffer was added. Enzymatic activity was assayed as indicated in Table 1.

obtained from Mann Laboratories, Inc. Coumarin was bought from Eastman Organic Chemicals.

Phildip Frost

CARL C. Levy

Dermatology Branch,

National Cancer Institute,

National Institutes of Health,

Bethesda, Maryland.

${ }^{1}$ Levy, C. C., and Weinstein, G. D., Nature, 202, 596 (1964).

${ }^{2}$ Levy, C. C., and Weinstein, G. D., Biochemistry, 3, 1944 (1964).

${ }^{3}$ Jevy, C. C., Nature, 204, 1059 (1964)

"Strittmatter, P., J. Biol. Chem., 236, 2329 (1961).

'Walaas, O., and Walaas, E., Acta Chem. Scand., 8, 1104 (1954).

${ }^{6}$ Walaas, E., and Walaas, O., Acta Chem. Scand.,10, 122 (1956).

\section{PHYSIOLOGY}

\section{Extracellular Recording of Converging Input on Cortical Neurones using a Flexible Microelectrode}

'THe convergence of different modajities of sensory input on restricted areas of the cerebral cortex has received much experimental attention in recent years ${ }^{1-5}$. Such investigations are valuable for an understanding of the integrative capacities of the cerebral cortex.

One cortical association area studied in detail at the cellular level ${ }^{4,5}$ showed differential responsiveness to various peripheral and central stimulations. Intracellular recordings indicated that excitatory and inhibitory postsynaptic potentials would, for many cells, determine the responsiveness of a cell, or the lack thereof, to converging input. Other convergences occurred before the level of the impaled cortical cell.

It seems likely, because of strong convergence of input, that non-primary, association areas may demonstrate especially good integrative capacities. Furthermore, a cell which is unequally responsive to different modalities of sensory stimulation may bo able to alter its pattern or extent of responsiveness under different conditions. It will be necessary ultimately to consider the likelihood of a differentially responsive cortical cell changing its discharge characteristies during certain behavioural situations. 